VSZ 2021/9

DRC 24 augustus 2020, Milligan (Sydney FC v. Al Ahli)

Afwijken van het dwingende solidariteitsmechanisme door middel van een contract niet toegestaan.

Volgens het door de Football Federation Australia Limited afgegeven spelerspaspoort stond speler Mark Daniel Milligan (Milligan) van 31 december 1997 tot en met 28 februari 2002 ingeschreven bij de Australische club Parramatta FC (Parramatta FC).

De Australische club Melbourne Victory FC, en de Saoedi-Arabische club Al Ahli (Al Ahli), zijn op 29 januari 2018 de definitieve transfer van Milligan naar Al Ahli overeengekomen tegen een transfervergoeding ten bedrage van USD 600.000 , te betalen in één forfaitair bedrag onmiddellijk na de ondertekening van de transferovereenkomst en nadat Melbourne Victory aan Al Ahli een geldige factuur heeft overgelegd. De clubs kwamen voorts in de transferovereenkomst overeen dat het bedrag zoals omschreven van bovengenoemde transfervergoeding inclusief de solidariteitsbijdrage was zoals genoemd in art. 21 en bijlage 5 RSTP. Overeengekomen werd dat Melbourne Victory de volledige verantwoordelijkheid op zich zou nemen voor de verdeling en betaling van de solidariteitsbijdrage aan de gerechtigde clubs.

Op 1 maart 2020 heeft Parramatta FC bij de DRC een vordering ingesteld tegen $\mathrm{Al} \mathrm{Ahli,} \mathrm{strekkende} \mathrm{tot} \mathrm{beta-}$ ling van het deel van de solidariteitsbijdrage in verband met de overschrijving van Milligan van Melbourne Victory FC naar Al Ahli. In het bijzonder heeft Parramatta FC verzocht om een bedrag van USD 5.520, overeenkomend met $0,92 \%$ van de transfervergoeding, vermeerderd met $5 \%$ rente per jaar 'as of the due date'.

In haar antwoord heeft Al Ahli betoogd dat de betaling van de solidariteitsbijdrage aan de vroegere club, Melbourne Victory FC, toekwam en dat Melbourne Victory volgens de transferovereenkomst de volledige verantwoordelijkheid op zich zou nemen voor de verdeling en betaling van de solidariteitsbijdrage aan de rechthebbende clubs. Volgens Al Ahli diende de vordering daarom jegens Melbourne Victory FC te worden ingesteld.

De DRC benadrukt dat het solidariteitsmechanisme een in de RSTP verankerd beginsel is, waarvan de partijen die een transfer- of uitleenovereenkomst ondertekenen, niet kunnen afwijken door middel van de inhoud van een contract. Wat de verdeling van de solidariteitsbijdrage betreft, is het bedrag dat in aanmerking moet worden genomen bij de berekening van de solidariteitsbijdragen die verschuldigd zijn aan de club(s) die betrokken is (zijn) bij de opleiding en de vorming van de speler, het bedrag dat daadwerkelijk is overeengekomen als totale vergoeding die de nieuwe club an de oude club verschuldigd is. Dit ongeacht of in de transferovereenkomst of uitleningsovereenkomst een andersluidende bepaling is opgenomen. De DRC verwijst naar de vaste rechtspraak, volgens welke de nieuwe club van de speler wordt gelast het (de) relevante deel (delen) van de solidariteitsbijdrage van 5\% over te maken aan de club(s) die betrokken was (waren) bij de opleiding en scholing van de speler. De DRC overweegt daarbij bovendien dat partijen, ten overstaan van de bevoegde FIFA-besluitvormende organen, in beginsel het recht hebben om van alle bij het geschil betrokken clubs de terugbetaling te vorderen van alle bedragen die die clubs naar hun mening te veel hebben betaald als solidariteitsbijdrage. De DRC concludeert derhalve dat Parramatta FC recht heeft op een solidariteitsbijdrage in verband met de transfer van Milligan van Melbourne Victory FC naar Al Ahli en dat in deze procedure succesvol kan vorderen.

De DRC oordeelt dat Al Ahli aan Parramatta FC het bedrag van USD 5.520 moet betalen, als solidariteitsbijdrage voor Milligan. Rekening houdend met zowel de vordering van Parramatta $\mathrm{FC}$ als met art. 2 par. 1 van bijlage 5 RSTP, beslist de DRC dat Al Ahli, in overeenstemming met de vaste rechtspraak, een rente van $5 \%$ moet betalen over het bedrag van USD 5.520 vanaf 1 maart 2018 tot de datum van betaling.

NB. Het solidariteitsmechanisme is een in de RSTP verankerd dwingend beginsel, waarvan partijen niet kunnen afwijken door middel van de inhoud van een transfer-, uitleenovereenkomst of andersoortig contract.

\section{VSZ 2021/10}

\section{DRC 27 augustus 2020, Ebecilio (Ebecilio Lorenzo Leroy v. Jubiloto)}

Club schadeplichtig jegens speler door onterechte beëindiging arbeidsovereenkomst met onmiddellijke ingang, recente contractverlenging indicatie van afwezigheid geldige reden voor beëindiging.

De Japanse club Jubiloto had een 'waarschuwingsverklaring' aan de Nederlandse speler Lorenzo Ebecilio (Ebecilio) gezonden. In die verklaring stelde Jubiloto dat Ebecilio herhaaldelijk zijn contractuele verplichtingen had geschonden. Ebecilio zou immers onder meer zonder voorafgaande kennisgeving niet naar de training zijn gekomen, afwezig zijn geweest op de training wegens een slechte fysieke conditie als gevolg van alcoholgebruik tot laat in de nacht en 's avonds laat contact hebben opgenomen met de tolk van Jubiloto terwijl hij 'enorm dronken' was. In deze context was Jubiloto van oordeel dat dergelijk gedrag het imago van Jubiloto ernstig had aangetast. Daarom verzocht Jubiloto aan Ebecilio om (i) zijn excuses aan te bieden aan zijn teamgenoten alvorens terug te keren naar de training, en (ii) zijn contractuele verplichtingen na te komen. Jubiloto stuurde Ebecilio een 'mededeling', waarin zij hem 
waarschuwde dat zijn arbeidsovereenkomst zou worden beëindigd 'indien hij niet uiterlijk op 3 februari 2020 aan het verzoek zou voldoen'. Nadat volgens Jubiloto geen verbetering optrad, heeft zij op 29 februari 2020 de arbeidsovereenkomst met Ebecilio met onmiddellijke ingang beëindigd. Ebecilio heeft vervolgens een vordering ingesteld bij de DRC en schadevergoeding gevorderd wegens beëindiging zonder geldige reden.

De DRC beklemtoont dat alleen een inbreuk of een fout van een zekere ernst de beëindiging van een arbeidsovereenkomst rechtvaardigt. Met andere woorden, alleen wanneer er objectieve criteria zijn op grond waarvan redelijkerwijs niet kan worden verwacht dat de arbeidsverhouding tussen de partijen wordt voortgezet, kan een contract voortijdig worden beëindigd. Een voortijdige beëindiging van een arbeidsovereenkomst kan slechts een ultima ratio-maatregel zijn.

De DRC is van oordeel dat Jubiloto niet het bewijs heeft geleverd dat de houding van Ebecilio Jubiloto schade heeft berokkend. In het bijzonder merkt de DRC op dat de partijen slechts één maand voor de beëindiging van de arbeidsovereenkomst door Jubiloto eind februari 2020 deze overeenkomst hadden verlengd. Het feit dat Jubiloto de arbeidsovereenkomst heeft verlengd, is een duidelijke aanwijzing dat zij over het geheel genomen tevreden was over de prestaties van Ebecilio. Bovendien benadrukt de DRC dat er onvoldoende elementen in het dossier stonden om vast te stellen dat het alcoholgebruik van Ebecilio buiten de werkuren een negatieve invloed op zijn prestaties bij Jubiloto heeft gehad. Wat de aantijgingen van onbehoorlijk gedrag betreft, was er, naast twee schriftelijke waarschuwingen en de beëindigingsbrief, geen afdoende bewijs in het dossier om de aantijgingen van Jubiloto te staven dat Ebecilio de club in diskrediet heeft gebracht en onbehoorlijk of beledigend had gehandeld, ondanks verklaringen van clubfunctionarissen, die naar het oordeel van de DRC als subjectief moeten worden beschouwd.

De DRC concludeert dat zij het betoog van Jubiloto dat het gedrag van Ebecilio de orde van Jubiloto had verstoord op een wijze die schadelijk genoeg was om de onmiddellijke beëindiging van de arbeidsverhouding te rechtvaardigen, niet kan volgen. Bovendien is de DRC van oordeel dat de beëindiging van de arbeidsverhouding onevenredig en overhaast was, aangezien Jubiloto aan Ebecilio geen kans heeft gelaten om zich te rehabiliteren nadat hij de verantwoordelijkheid voor eventuele fouten had aanvaard en had verklaard dat hij bereid was om de arbeidsverhouding voort te zetten. Jubiloto had immers mildere maatregelen kunnen nemen om Ebecilio in staat te stellen te bewijzen dat hij zijn gedrag zou verbeteren en zijn contractuele verplichtingen jegens Jubiloto in de toekomst zal nakomen. De DRC concludeert dat de resterende waarde van de arbeidsovereenkomst vanaf de vroegtijdige beëindiging ervan door Jubiloto tot normale afloop EUR 1.336.363 bedraagt. $\mathrm{Na}$ de volledige en specifieke omstandigheden van deze zaak volledig te hebben onderzocht, beslist de DRC dat Jubiloto aan Ebecilio een schadevergoeding wegens contractbreuk van EUR 1.336.363 dient te beta- len, welk bedrag door de DRC als een redelijke en gerechtvaardigde schadevergoeding wordt beschouwd. Bovendien is $5 \%$ rente per jaar verschuldigd over voornoemd bedrag, vanaf de datum van de onderhavige beslissing.

NB. Er is een hoge drempel voor een club om tot onmiddellijke beëindiging van een arbeidsovereenkomst te mogen overgaan volgens de DRC. Een beëindiging van de arbeidsovereenkomst is al snel onevenredig en overhaast als de verwijten aan het adres van de speler onvoldoende kunnen worden gestaafd met bewijs en/of indien een speler niet eerst een kans heeft gekregen om zich te rehabiliteren. Een recente verlenging van de arbeidsovereenkomst zal het lastiger maken voor een club om aan te tonen dat er geldige redenen voor beëindiging zijn.

\section{VSZ 2021/11}

\section{DRC 29 september 2020, Georigi Kitanov (Georgi} Kitanov v. AFC Astra)

\section{Arbeidsovereenkomst van voetbalspeler mag op grond van Roemeens recht worden geschorst als gevolg van COVID-19.}

Op 5 mei 2020 heeft de Bulgaarse speler Georgi Kitanov (Kitanov) tegen zijn oud-werkgever, de Roemeense club AFC Astra (Astra), een vordering bij de DRC ingesteld. Hij vordert achterstallige salarisbetalingen, vermeerderd met rente. In zijn vordering wees Kitanov erop dat Astra zijn loon niet volledig zou hebben betaald, ook niet nadat zij in gebreke was gesteld. Astra weigerde nakoming van de arbeidsovereenkomst en betaling van het volledige salaris vanwege een 'noodverordening' die door de Roemeense autoriteiten op 16 maart 2020 was bekendgemaakt. Astra stelde dat zij de arbeidsovereenkomst en salarisbetalingen mocht schorsen en Kitanov recht zou hebben op slechts $75 \%$ van het Roemeense wettelijke basisinkomen dat door de staat Roemenië zou worden betaald. Volgens Kitanov was deze beslissing ongeldig en onwettig. Kitanov heeft uiteindelijk de arbeidsovereenkomst eenzijdig opgezegd op grond van art. 14bis RSTP omdat hij een totaalbedrag van meer dan drie maandelijkse salarissen van Astra tegoed zou hebben. Astra verzocht in de procedure om afwijzing van de vorderingen van Kitanov en voerde aan dat - in het licht van de uitbraak van COVID-19 - ook het Roemeense recht op de onderhavige zaak moest worden toegepast, aangezien laatstgenoemd recht meer gedetailleerde regels betreffende de sluiting, uitvoering en beëindiging van arbeidsovereenkomsten zou bevatten. Astra heeft voorts verklaard dat de schorsing van de arbeidsovereenkomst van Kitanov niet was gebaseerd op 'overmacht', maar op bepalingen van de Roemeense Arbeidswet. 